Historic, archived document

Do not assume content reflects current scientific knowledge, policies, or practices. 



\section{New Farm and Orchard Products are Propagated by Coleman Orchardist}

Next to Santa Rosa. the home town of Burbank in California, no other town in the U. S. is more noted than Coleman for new products cent out over the worid, of both orchard and farm. The Halkert pecan is a great favorite and is being extensively propagated by planting both nuts and trees and top-working native trees over Texas and other States. The nuts have been shipped to South America to be planted. The Lilly Pecan is a favorite with some growers. This variety was first introduced under the name of Alexander and afterwards changed to the shorter name of Lilly.

The Halbert Hybred Corn, a drouth resisting variety, is being grown with great satisfactioin over Texas and other states.

The Halbert Honey Watermelon is a universal favorite on the continent of America and seed have been sent direct from Coleman to three of the continents: France in Europe; Cape Colony, in Africa, and New South Wales, in Australia. The Rubber Rind Watermelon is not such a favorite. but it is grown for shipping and hauling over rough roads to market.

The Halbert Perfection Watermelon is the latest new variety and is having a wonderful sale. To date approximately $\$ 3,000$ worth of seed have been sold of this variety and sent by mail. express and freight all over the U. S. and money came direct to Coleman to be spent among us and about $\$ 500$ more yet to be sold, all from a 25 acre patch of the Perfections.

All the above new varieties of farm and orchard products were originated and introduced by the best known farmer in Texas, our fellow citizen H. A. Halbert, on his small farm and pecan orchard two miles east of Coleman, on Hord's Creek.

Mr. Halbert is still busy at originating new varieties. His next introduction will be his Long-Green-Rind Honey Melon with a hard unbreakable rind which he will name "Longfellow." Then he will breed the sweet tender flesh of his Honey Melon inside of a White Pie-Melon and call it "MelonPie." He further contemplates crossing two fine varieties of pecans and breed a still better variety than is yet known.

If the U. S. patent laws protected a farmer in what he originates as it does an inventor, $\mathrm{Mr}$. Halbert would today be a near millionaire from small royalties on the seed sold from the products he has originated. As it is he is making a good living and can have the satisfaction that he is doing some good to his fellowman by giving them some improved food products.

Mr. Halbert's seed trade has so increased since he started about 20 years ago with a few pounds of $\mathrm{Hal}$ bert Honey seed and a five-acre patch. until it takes over 100 acres and many thousand pounds of seed to supply the demand made upon him for his pure seed. 


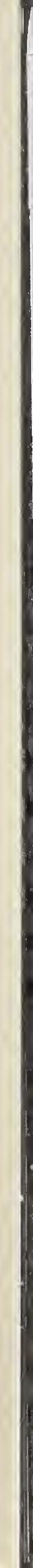

